\title{
Theorizing Jewish Ethics
}

\section{Alan Mittleman}

The Jewish Theological Seminary, USA

e-mail:almittleman@jtsa.edu

\begin{abstract}
:
The concept of Jewish ethics is elusive. Law occupies a prominent place in the phenomenology of traditional Judaism. What room is left for ethics? This paper argues that the dichotomy between law and ethics, with regard to Judaism, is misleading. The fixity of these categories presumes too much, both about normativity per se and about Judaism. Rather than naming categories "law" and "ethics" should be seen as contrastive terms that play a role in fundamental arguments about how to characterize Judaism.
\end{abstract}

Keywords: Judaism, ethics, Jewish philosophy

This paper was first published in the volume

Schumann A. (ed), Pragmatic Studies in Judaism. Gorgias Press, 2013, pp. 115-134.

The concept of Jewish ethics is chronically ill defined. As a category, what should Jewish ethics include? What should it exclude? How should the concept guide our interpretation of Jewish texts? Indeed, does it have heuristic value or does it misdirect us, prompting us to lay on a Procrustean bed materials that are better suited to other rubrics? Does the concept even have legitimacy?

From a point of view external to Judaism, the concept seems unproblematic. Any number of comparative religion books, such as Charles Matthewes's recent Religious Ethics speak in a descriptive way of Jewish ethics, alongside those of other world religions. Matthewes assumes that the term picks out relevant normative features of the Jewish textual inheritance and that these form a substantial sub-field of Jewish thought. He assumes that 'Jewish ethics' is fully comparable to 'Christian ethics;' that these are meaningful and fruitful terms. From an internal point of view, however, matters are not so straightforward. Consider, as our point of departure, Michael Wyschogrod's statement, in his neo-Orthodox theological tour de force, The Body of Faith, that 'ethics is the Judaism of the assimilated' [11, p. 181]. For Wyschogrod, the urge to construct a category of Jewish ethics, to theorize it, and to accord it centrality is typical of liberal, non-halakhic modern Jews. Jewish law, halakhah, should be the authentic category of Jewish self-understanding. The Jewish ethics project of liberal modernity is an attempt to substitute something purely rational, universalizing, cross-culturally intelligible and respectable for the highly particular, divinely revealed law to which pre-modern Jews gave their allegiance. Jewish ethics is, on this view, a kind of political statement, a polemic on behalf of a reconstructed non-offensive Judaism.

This essentially ideological argument has a point. ${ }^{1}$ At least since the time of Moses Mendelssohn, Jewish modernists have de-centered Jewish law and emphasized ethics as the salient category of Jewish representation both to insiders and outsiders. Any diminution of the central role 
of halakhah is an historic break with the time honored model of Jewish self-understanding. But this is not to say that pre-modern Jews understood themselves solely within the framework of what we call law. Our concepts of law are no less problematic, when applied to traditional Judaism, than our would-be concepts of Jewish ethics. Common modern concepts of law are often positivistic; they are often tied to political concepts, such as sovereignty. They are in many ways ill-suited to map halakhah. How to sort this out constitutes a deeper problem than may be apparent from the ideological polemics of modern Jewish discourse. A number of modern Jewish thinkers have applied themselves to this nest of problems. I want to consider the work of a few of them here, assess the strengths and weaknesses of their approaches, and then propose my own approach to any putative concept of Jewish ethics. First, however, let me clarify more fully what is at stake.

At stake here is more than traditionalist Jews continuing to assert the indispensability of halakhah. Bundled into the "traditionalist" claim is the view that halakhah is not only necessary but sufficient; that halakhah comprises all norms relevant to human conduct, at least for Jews. To assert that some other body of norms pertains, indeed, that some non-halakhic ways of thinking about norms are required is to detract from the omni-sufficiency of halakhah. The omni-sufficient view is not just about how we categorize those norms which govern Jewish conduct. It is about the origin of such putative norms; the metaphysical background from which normativity per se emerges. The partisans of an omni-sufficient halakhah claim that the halakhah is God-given. Mere ethics seems to have a lesser pedigree or at least a more circuitous one. At issue then are old and weighty controversies about revelation, reason, and nature. The tension among these terms is not insuperable, but it is deeply felt. Issues of moral anthropology and moral epistemology are also in play. Who is the subject of norms? Why is such a subject so bound? What relation does the subject's own reason and will have vis-à-vis norms? How do we, how can we know what is legitimately normative? If there is an independently cognizable realm of moral normativity over and against the halakhah, then what do we need halakhah for? If ethics is available to critique halakhah or if it serves as the telos of halakhah, then the majesty and sovereignty of halakhah - what a German Jewish philosopher called der Totalitätsanspruch der Thora (the Torah's claim to totality) - is impugned. The scope and embodiment of norms is also at issue. Perhaps halakhah, while irrefragably central, is not sufficient. Perhaps it recognizes its own insufficiency by commanding ethical counterweights, balances, and corrections. Halakhah, one might say, needs ethics as a supererogatory modality; the two complement one another. But then again, if the halakhah stipulates a need for a normative framework in excess of its own standards, ethics remains a creature of the halakhah. If Jews are commanded (as they are) to go beyond the letter of the law (lifnim me-shurat ha-din), and the latter is thought to constitute ethics, then in what sense is ethics really separate from law? Ethics would be a moment internal to halakhah.

Another kind of consideration that bears on our definitional question invites the perspective of political theory. What kind of social world does the halakhah assume, require, or intend? Spinoza famously argued that Jewish law was law only insofar as it comprised the statutes of an ancient commonwealth. Law requires not only jural agencies but a fully articulated polity. In the absence of that political infrastructure, for Spinoza, Jewish law no longer has legal - or any - authority. Maimonides also framed the halakhah as a constitution. His code, the Mishneh Torah, culminates in the laws of kings and warfare - halakhah ideally requires a full political instantiation. The Princeton scholar, Leora Batnitzky, in her recent book, How Judaism Became a Religion, sees most of the modern Jewish thinkers from Mendelssohn on engaged in a program of de-politicizing Judaism, indeed, of creating "Judaism." On this account, the transformation of Torah into religion simpliciter was designed to provide a medium whereby Jews could nullify the political impulses of classical Jewish self-understanding and render their Judaism compatible with the overarching political claims of modern nation states. Given a Westphalian Judaism so to speak, a Judaism qua religion, ethics fills the space where a comprehensive, politically instantiated legal order once prevailed. Even the truncated exilic forms in which Jewish political expression persisted were unacceptable to someone like Mendelssohn. Although Mendelssohn did not seek, like the 19th century Reformers, to abolish 
the law, he did reframe its significance. Whatever power the law retains, it does so in order to promote moral development and cultivation - Bildung. As Judaism becomes religion and religion is segregated from the political, halakhah is domesticated to ethics. In short, fundamental questions of the nature and meaning of Torah are at stake in the question of Jewish ethics. No wonder the question is so fraught.

There are, it seems to me, three broad positions that modern thinkers have taken on the relation of ethics to halakhah/law. The first is that ethics ought to be the dominant category. Ethics forms the content, point, and purpose of halakhah. "Ethics" is given an expansive rhetorical and conceptual role in the representation of Judaism, both to insiders and outsiders. To speak of Judaism is to play a moral language game. The great works of Jewish thought deriving from liberal Jews such as Moritz Lazarus and Hermann Cohen in the 19th and early 20th centuries exemplify this position. Let's call this position the sovereignty of ethics. The second point of view, which arguably arises historically as a reaction to the excesses of the first, is what I have called the omni-sufficiency of the halakhah. On this view, Judaism is all law - ethics, as an independent normative sphere, cannot gain a toehold. All relevant normative reasoning takes place within the four ells of the halakhah. There might well be an independently cognizable or theorizable sphere of ethics, but it is irrelevant for Jews. Talk of a Jewish ethics is, at best, merely a way of speaking about the halakhah as applied to topics the non-Jewish culture calls ethical. There is, for example, a great deal of Jewish biomedical ethics today which consists entirely of halakhah applied to medical topics. On the view that advocates the omni-sufficiency of halakhah there is nothing wrong with calling such work "Jewish biomedical ethics" as long as we understand "ethics" as a proxy for "halakhah." This view assumes that all ethical problems are resolvable into legal problems and that legal problems can be resolved to greater or lesser satisfaction with the tools of, in this case, the rabbinic trade. Here, the term "ethics" may linger on but its content is attenuated; it is not much more than a verbal gesture. The strongest case for the exclusive dominance of the halakhah was made by Joseph Soloveitchik. Disciples such as Aaron Lichtenstein and Sol Roth, as well as Marvin Fox make the case as well.

A third position sees a division of labor between the two categories. Ethics picks up where the law leaves off. This is the view of the great medieval exegete, Ramban, and may also be said to characterize the whole tradition of sifrut ha-musar (the literature of moral exhortation). On this view, halakhah is necessary but not sufficient. Rahmana liba ba'ei - God seeks the heart - as the Talmud puts it. Performance of commandments is not enough. Mitzvot tzrikhot kavannah: the commandments require intention. Intention itself is complex and requires cultivation. The inward dimensions of love, fidelity, enthusiasm, awareness, devotion, and aspiration are required. Some thinkers thus see a natural divide between law and ethics along the lines of outer (action) vs. inner (attitude). The Musar Movement in the 19th century argued that although Torah was studied and obeyed, yirah (fear of God) was absent. Without yirah, Torah study and observance were almost useless. The inner had to be pursued with the same intensity as the outer. Bahya ibn Paquda made a similar case in the 11th century. This division of labor between the inner and the outer is tacitly or explicitly assumed by those like Joseph Dan, who write on the history of Jewish ethics. Dan, in trying to constitute his subject matter, relegates ethics to an attitudinal accompaniment of the performance of mitzvot. $^{2}$ There is something to be said for this view, of course, but it is also deeply problematic. It assumes, for example, that "ethics" and "halakhah" are rather static terms that describe two categorically distinct domains of content, one explicable in terms of intentionality, the other in terms of performance. It probably fails as an incipient theory of action with its rigid dichotomy between act and intent. It also fails to grasp the ethical content of the halakhah, relegating it to the attitude of those who enact it rather than to the inherent qualities of the law per se. Nor does it take notice of the purposes of the law. Its agent-centeredness is both a strength and a weakness.

Another way of sustaining a law/ethics distinction, which avoids the inner/outer dichotomy, is to say that law is sustained by coercion and sanction while ethics is sustained by voluntary 
consent (albeit consent to fully normative imperatives). This is essentially a Kantian approach, distinguishing between perfect and imperfect obligations. Both forms of obligation are necessary for social order. Ethics is a device which acknowledges the limits of law at least insofar as its enforcement mechanisms are concerned. This position, call it ethical-legal complementarity, is exemplified by the work of Shimon Federbush in his Hebrew study, Ha-Musar ve Ha-Mishpat $b^{\prime}$ Yisrael (Ethics and Law in Israel).

The first position is given a paradigmatic expression in a great 19th century work, Moritz Lazarus's Die Ethik des Judentums. ${ }^{3}$ Lazarus, a German-Jewish professor of psychology and a leader of Liberal (Reform) Judaism in the Second Reich, was immensely popular among his acculturated German coreligionists in the 19th century but is largely forgotten today. He presents, far more sweepingly and robustly than Mendelssohn, a thorough ethicization (Versittlichung) of Judaism. Judaism is essentially, if not exclusively, ethics. Ethics becomes the master category to which all other aspects of Judaism are ordered or, should that not succeed, discarded (as in the case of mysticism). His main work, Die Ethik des Judentums (The Ethics of Judaism) is the first modern systematic effort to interpret Biblical and rabbinic religion entirely through the prism of ethics.

Lazarus is concerned, on the one hand, to show that Judaism qua ethics is in broad accord with Kantian ethics. On the other hand, he is dismissive of those who would equate or subordinate Judaism to Kant. ${ }^{4}$ He thus walks a narrow line between Judaism as a form of autonomous moral consciousness and Judaism as a heteronymous religious system. He attempts to preserve the naïve, authentic voices of traditional Jewish texts and to relate them to the most compelling contemporary intellectual voices. As a psychologist rather than a philosopher, Lazarus seeks a more or less empirical basis for ethics. Ethical consciousness is not intuitive or naturalistic; it is informed by the "ought" not the "is," by reasons not causes, as we would say. The concept of ethics signifies an ideal sphere above natural existence toward which human beings, both personally and socially, ought to strive. Nonetheless, Lazarus does not go in a fully Kantian direction and divorce moral imperatives from human drives, feelings and desires. ${ }^{5}$ Ethics arises from a drive toward the Good (Trieb zum Guten), from a feeling of obligation (Gefühl der Verpflichtung), which issues into rational assent [7, Vol. I, p. 115]. There is no small risk of incoherence in Lazarus's view; it is also immediately problematic with respect to Judaism. If Judaism is equivalent to ethics and ethics arises from a sentiment of obligation, then the entire theistic framework of Judaism becomes irrelevant. Lazarus therefore attempts to preserve the distinctive monotheistic assumptions of Judaism by making God, the author of ethics, pervasively moral. Lazarus, like Cohen after him, removes all traces of divine voluntarism. That God commands an imperative does not make it right; God commands it because it is right. God too is subject to moral law. For a human being then, to will the moral law of one's free will is simultaneously to do God's will. 'Morally good and pleasing to God; moral law and divine command - for Judaism these concepts are completely inseparable' [7, Vol. I, p. 85], translation my own. Inseparable but, he adds, not identical. God's command and the moral law are related through a third term, the concept of holiness.

Holiness plays a critical role in Lazarus's thought. For Lazarus, the Biblical expression for the conjunction of divine command and the moral law is 'You shall be holy, for I the LORD your God am holy' (Leviticus 19:2). God does not say 'you shall be holy because I will it' or '... because I command it.' God's own being as holiness is morality.

The fundamental teaching of Judaism runs: because the moral is divine, therefore shall you be moral and because the divine is moral, therefore shall you be become like God.... The highest form and the final end of all human life is imitatio dei (Gottähnlichkeit) [7, Vol. I, p. 89], translation my own.

The being or nature (Wesen) of God is not an object of Biblical or rabbinic speculation. What we are given instead is God's holiness and holiness is explicated by moral attributes. The call 
to holiness is a call to participate in the creative power of the moral world-order; a call to bring about the fulfillment of the purpose of creation.

The holy God is 'primordial form of all morality' (Urgestalt aller Sittlichkeit). As much as he invokes 'God' as the giver of the moral law, 'God' also seems to be nothing more than the Jews' way of speaking about 'the idea of the Good,' 'the Spirit of morality' (Geist der Sittlichkeit) [7, Vol. I, pp. 89-90], translation my own. Similarly, the concept of revelation is deflated into the deliverances of moral reason. Long before the revelation of commandments at Sinai, Abraham kept the entirety of the law (Mishnah Kiddushin 4:14), which he attained through his own reason [7, Vol. I, p. 91]. Autonomous moral reason is thus the source of moral instruction. Given his penchant for modernist demythologization, what role other than a notional one does Lazarus reserve for God? The answer is that God and religion provide a conceptual framework which does not infringe the independence and self-sufficiency of ethics (Selbstständigkeit des Ethischen) but rather sharpens (Einschärfung) its authority. Ethics does not derive its authority from God. We are, rather, to take the self-sufficient ethics which our reason discovers and dedicate our lives to the furtherance of ethics for the sake of ethics. We imagine this autonomous, self-sacrificial, total commitment as dedication to God, the highest possible object of our intentionality [7, Vol. I, pp.109-110]. Our ethical intentionality thereby never serves our mere self-interest. As a quasi-Kantian, Lazarus eschews any prudent or hedonistic ground for ethics, insofar as it would compromise the majesty and freedom of the ethical realm. Our moral aloofness from the pursuit of self-interest, which attests to the objectivity and universality of the moral law, is also given a vivid portrayal in the notion of a sovereign God.

The idea of holiness, the hallowing of all of life, is the master principle of Jewish ethics. 'Holiness means nothing other than the complete ethicization [Versittlichung] of human society, of humanity as such' [7, Vol. I, p. 187], translation my own. The principle of holiness directs us to take life seriously and to identify those values which we ought to take with utmost seriousness. In Judaism's construal of holiness, we find two domains: the ritual and the ethical per se. For Lazarus, the ritual domain - expressed in the numerous Biblical huqim, which he calls, following 19th century Reform usage 'ceremonial laws' - is not moral per se but nonetheless serves a moral telos. The ritual laws build a notional world on top of the natural world such that they remind the Jews that they belong both to the natural world and to something beyond. Insofar as the ritual laws order and transform natural human functions, such as eating or resting, they have a broad pedagogic role; they are pointers toward both nature and transcendence [7, Vol. I, pp. 191-192]. The ethical and the religious are inextricably intertwined. Neither concept is fully intelligible without the other in Judaism although it is clear that the concept of the religious, of religious holiness, is dependent upon the concept of ethics, of ethical holiness. Ethical holiness has its own abstract self-sufficiency. An integrated, flourishing human life, however, requires that ethical holiness be enacted within the framework of religious holiness. Why? Because although we can give ourselves fully to the life of morality, we cannot fully cognize the sublime mystery (erhabenes Geheimnis), that is, the divine, at the heart of that life [7, Vol. I, p. 196]. For Lazarus, it seems, the fully flourishing life is a life cognizant of that mystery. Religion, Judaism, brings us to the conceptual boundary at which the mystery can be acknowledged. Thus, Lazarus tries to preserve the category of religion from assimilation to the category of ethics. At the same time, he orders all of the normative contents of Judaism to an ethical paradigm. The views of Hermann Cohen and Emmanuel Levinas are philosophically much more complex than Lazarus's but they plow, I would submit, the same furrow. Ethics is sovereign.

The second position is a reaction to the first. One of its exponents is the famous Rabbi Joseph B. Soloveitchik. In Halakhic Man, Soloveitchik sets up a dichotomy between 'religious man' and 'halakhic man.' This sounds a bit surprising, since ordinarily one would think that Judaism is a religion and the halakhah is a religious law. Soloveitchik's dichotomy draws from similar dichotomies prevalent in the German culture in which he received his university education. The liberal rabbi, Leo Baeck, for example, wrote a famous anti-Christian or at least anti-Pauline 
polemic called 'Romantic Religion.' Baeck contrasted the sober, ethical, rational Apollonian religion of classical Judaism - the essence of which he found in an autonomous morality of a vaguely Kantian kind - to the impassioned oceanic spirituality of the Romantics. Paul, on Baeck's account, becomes the Urvater of romanticism. Baeck was in turn using and 'transvaluing' Nietzsche's dichotomy from The Birth of the Tragedy of Apollonian and Dionysian cultures. Soloveitchik was probably also aware of Christian theologians such as Troeltsch, who in Die Absolutheit des Christentums, exempted Christianity from the category of religion - religion was reserved for everything other than Christianity. From such presumed sources, Soloveitchik constitutes a halakhic sphere that is not only essentially other than the sphere occupied by 'religious man,' but it is also higher. In this, he follows Kierkegaard, adapting Kierkegaard's stance of faith vis-à-vis the ethical as the stance of halakhic man vis-à-vis religious man.

For Soloveitchik, religious man, homo religiosus, is also ethical man. Ethical man construes the world as a domain which one yearns to ameliorate, escape or transcend. Homo religiosus strives for moral perfection; he sees the world as an obdurate obstacle to his moral-religious quest. Halakhic man, by contrast, is unencumbered by such romantic passions. He sees the world as a field of problems to be cognized and of opportunities to be exploited through halakhically defined action. Homo religiosus

longs for a refined and purified existence. The riddle in existence and the eternal problem that hovers over the face of being leads him beyond the bounds of concrete reality.

By contrast, 'halakhic man's approach to reality... is devoid of any element of transcendence' [9, pp. 16-17]. Halakhic man is not on a quest. He already knows where he will end up because he knows from whence he starts out: with an a priori body of

fixed statutes and firm principles... [a]n entire corpus of precepts and laws guides him along the path leading to existence. Halakhic man, well furnished with rules, judgments, and fundamental principles, draws near the world with an a priori relation. His approach begins with an ideal creation and concludes with a real one [9, p. 19].

Soloveitchik likens this phenomenon to mathematics. Mathematics exists, in his view, in an a priori ideal way but is applied to a correlative, concrete world.

Although Soloveitchik as a thinker deeply influenced by Neo-Kantianism - he wrote his dissertation on Hermann Cohen - is careful not to reify or ontologize the Torah in the manner of mysticism, he does constitute Torah as an a priori transcendental principle of normativity. No independent ethic, certainly nothing answering to the term 'Jewish ethics,' is needed. And yet Soloveitchik has to allude to ethical considerations. He asserts, for example, that

Halakhic man's most fervent desire is the perfection of the world under the dominion of righteousness and loving-kindness - the realization of the a priori, ideal creation, whose name is Torah (or Halakhah), in the realm of concrete life.

'The great Torah giants,' he tells us, 'the halakhic men par excellence, were indeed champions of truth and justice. They glowed with a resplendent ethical beauty' [9, pp. 94-95]. Is he being inconsistent? How can his view accommodate this assertion of ethical values vis-à-vis the halakhah? In brief, Soloveitchik sees the cognitive activity of halakhic man, which resembles that of the mathematician or the scientist, as tending always toward a normative goal. The astronomer studies the heavens to understand the motion of the heavenly bodies. Halakhic man wants to understand this too - in order to know how to apply the Jewish calendar or sanctify the new moon. The very pursuit of knowledge, both among scientists and halakhic men, has a normative 
motivation and thrust. Ultimately, the halakhic man wants to cognize the universe in order to know how to act within it; there is a seamless fit between knowing and doing. To know the world is to know God's glory, which means to know God's emulable attributes of action - which are the source of 'the ethical life.' When we fix on the 'whole of being and cognize it' we implement the ethical ideal [9. p. 64]. Thus Soloveitchik bundles normative, specifically ethical purposes into his philosophical anthropology of halakhic man. He uses terms such as 'ethical beauty,' 'ethical ideals,' and 'ethical life' but such terms do not significantly qualify, complement, let alone criticize or oppose the skein of life of halakhic man. They arise from that life and are nestled within it. Indeed, Soloveitchik contrasts the resistance of religious man to ethical norms, which homo religiosus feels as external and coercive, with the internal, voluntary, near autonomous acknowledgement of the commandments by halakhic man. The commandments seem to him 'as though he discovered the norm in his innermost self' $[9$, p. 65].

The ethical has no independent standing in Soloveitchik's thought despite his pervasive, foundational concern with normativity. A similar view, albeit expressed in a more discursive fashion, is found in his son in law, Rabbi Aharon Lichtenstein's important essay, 'Does Jewish Tradition Recognize an Ethic Independent of Halakhah?' ${ }^{6}$ Lichtenstein's argument is highly nuanced. He acknowledges that the rabbinic tradition recognizes a lex naturalis or, more minimally, a natural morality, see Lichtenstein in [6, p. 104]. The question is whether that independent preSinaitic ethic has any relevance, legitimacy or authority for a post-Sinaitic Jew. Lichtenstein's position is that this independent ethic is effectively aufgehoben in the halakhah. His question is whether

the demands or guidelines of Halakhah are both so definitive and so comprehensive as to preclude the necessity for - and therefore, in a sense, the legitimacy of - any other ethic, see Lichtenstein in [6, p. 105].

The answer is yes, given a suitably capacious conception of the halakhah. The phrase 'any other ethic' is quite deliberate. For Lichtenstein at once asserts that 'Halakhah constitutes - or at least contains - an ethical system,' see Lichtenstein in [6, p. 106]. He categorically rejects views such as those of Yeshayahu Leibowitz, which anchor halakhah in pure divine command. Such 'quasifideistic voluntarism' is not consonant with the 'main thrust of the tradition' in Lichtenstein's view. Halakhah must not be divorced from a recognizable morality. Is halakhah then parallel to morality; is morality a complement or an alternative to halakhah? Lichtenstein rejects this line of thinking. The fact is that the 'Halakhah is multiplanar and many dimensional; that, properly conceived, it includes much more than is explicitly required or permitted by specific rules.' And thus, 'we shall realize that the ethical moment we are seeking is itself an aspect of halakhah,' see Lichtenstein in [6, p. 106]. Those elements of supra-legal obligation in the halakhah, such as acting lifnim me-shurat ha-din, are themselves parts of halakhah. A highly textured, 'multiplanar' halakhah leaves no conceptual space for Jewish ethics. Thus, on the view of the omni-sufficiency of halakhah ethical considerations are not absent, bracketed, or neglected. They are firmly subordinated to an expansive conception of Jewish law which deprives them of any independent standing.

The third view is that of complementarity between a halakhah thought to require some additional normative warrant and ethics. As I mentioned, there are at least two ways of constituting this view. The first is based on a presumed distinction between inner attitude (ethics) and outward action (law). The second is based on the fact (and limits) of enforcement mechanisms, that is, ethics picks up where law must, in the nature of human social life, leave off. Nachmanides appears to exemplify this view in his comment to Deuteronomy 6:18: 
Do what is right and good in the sight of the LORD that it may go well with you and that you may be able to possess the good land that the LORD your God promised on oath to your fathers.

Nachmanides takes doing what is 'right and good' (ha-yashar v'ha-tov) to mean seeking compromise (peshara) and renouncing one's full legal rights (lifnim me-shurat ha-din) for the sake of comity. He acknowledges the limits of the law and the need for an internal sense of moral duty or virtue. But note, however, that ethics in this sense is commanded by the law. The imperfect duty, to use Kantian language, of seeking compromise and acting lifnim me-shurat ha-din is a consequence of the perfect duty of 'doing the right and the good.' Ethics is given a certain standing on the complementarist account but it is consigned to the penumbra of the law. Perhaps its standing is so dependent on the law that this view is simply notional and reverts to the affirmation of the omnisufficiency of halakhah.

A determined effort to keep law and ethics conceptually distinct yet practically related is found in the work of a neglected Jewish moral and political theorist, Rabbi Shimon Federbush (1892-1969). In his posthumously published work Ha-Musar ve-Ha-Mishpat b'Yisrael (Ethics and Law in Israel), Federbush argues that law and ethics are identical in content [3, pp. 11-21]. The distinction between them arises from the different contexts in which they are employed. Federbush considers that the distinction between law and ethics may be that of act and intention, but he rejects this - rightly, in my opinion - in favor of an integrated view of action. Intention is integral to the description of an act, as exemplified in Biblical criminal law which distinguishes between manslaughter and homicide on the basis of intention. If law and ethics care equally for the integrated expression of intention and performance, then the distinction between them must lie elsewhere. He also rejects Stammler's distinction between acts that are essentially private, which on Stammler's account constitute ethics and acts that are essentially public, which constitute law. Individuals cannot be neatly distinguished from their social milieus, he argues. Nor does ethics lack a social address. The Biblical prophets, whom he portrays as moral critics, spoke to the public. The Torah intends a social ethics, which Stammler's view must fail to take into account.

The view that Federbush settles on distinguishes between acts that are capable of being coerced by an external authority and acts that have no functional sanction other than conscience. Coercion (kefiyah) distinguishes between law and ethics. This is to say that the content of law and ethics is in principle identical; the post facto availability of coercion is what allows for the distinction. Federbush senses that the criterion of coercion is necessary but not sufficient, however. Is there no criterion that allows for an essential distinction between law and ethics, as opposed to an adventitious, contextual one? He holds that there is such a criterion and locates it in social need. In any given human society, there is an underlying dynamic of normativity (hoq). Social actors over time decide how much of this normativity must be structured into law and how much can remain rather less structured as ethics. What are the necessary minima for social order? The underlying norms (huqim) without which society cannot survive become laws; the ones that are best left at large are ethics. Context, history, and human interest determine the dichotomization of normativity into ethics and law. This is a rather thin essentialism, which in my judgment is the best kind to have.

Now all of these views, their differences notwithstanding, share a common interest - to distinguish theoretically between ethics and law and to fix their conceptual relations. All thus presume that the terms designate categories which have in principle independent, identifying features. The categories of law and ethics, whatever the eventual relations between their contents, are prima facie separate and distinctive. It is this assumption that I want to criticize. It is not my purpose to argue in a global way that ethics and law are identical. Rather, I want to expose the presupposition of their categorical difference in Jewish thought to criticism.

To begin, Jewish thinkers who ponder the problem of Jewish ethics all seem to assume that ethics in the Western context is a discrete, distinguishable, stand-alone endeavor. Ethics must either 
rule, be conquered or be yoked in partnership to law. They do not seem to have noticed that modern Anglo-American philosophical ethics is full of criticism of what Bernard Williams mordantly called 'the morality system.' Philosophers such as Williams, MacIntyre, and already in the 1950's, G.E.M. Anscombe raised serious questions about whether ethics can be a coherent category. For Williams, the obsession of 'the morality system' with obligation, with what one ought to do (in some special sense of 'ought'), orients ethics away from questions of how one should live toward questions of what agents must do. It fixes ethics on the judgment of agents, which resembles 'the prerogatives of a Pelagian God. ${ }^{, 7}$ Both MacIntyre and Anscombe have also tended to construe ethics as a false religion. (Although, unlike Williams, they each want a true one.) MacIntyre would explode the compactness and categorical integrity of ethics and conduct moral enquiry through historical, literary, anthropological and sociological interrogation. He questions the idea that morality is a distinct phenomenon, separable from, for example, the purity taboos of archaic societies. The very act of distinguishing an identifiable domain labeled 'morality' to be studied by a conceptually distinct method known as 'ethics' is a matter of historical contingency. Anscombe found the allegedly unique moral sense of 'ought' incoherent. It is a survival from a Christian age, in turn shaped by the Torah. For Anscombe, without a belief in divine law, 'ought' and 'obligation' in the commanding sense ethics ascribes to these terms cannot be sustained. 'It is as if,' she writes 'the notion "criminal" were to remain when criminal law and criminal courts had been abolished and forgotten."

Views such as these suggest that the modern Jewish thinkers, whatever their position on ethics and law, have too much confidence in the concept of ethics as such. Kant looms too large for them. Whichever tack they take, they believe that they need to reach an accommodation with ethics. A putative concept of ethics makes demands on them and they must respond. But if ethics itself is a historically contingent category, if it develops meaning only through intensional contrasts with other normative terms and if none of these are fixed, why should Jewish thinkers have to respond to the demand? Rather than assume that the ethics/law dichotomy is a formidable problem, why not see the whole business as a contingent semantic matter? There are several reasons that impede that Wittgensteinian resolution.

One reason the dichotomy seems so formidable is because the normative rules and conclusions of halakhah sometimes violate the modern sense of justice, equity, fairness, and so on. Halakhic approaches to the status of women are a leading example of this. Insofar as halakhah is particular to the Jews and ethics is thought to be universal, it is easy to frame this tension as one between law and ethics, a particular norm versus a universal standard. Conceptually, however, it would be just as easy to frame the tension as one between competing impulses, values, principles and goals within the halakhah. The Jewish moral tradition is rich with such tensions and with the resources to negotiate them. Casting conflicts of value into the dichotomous terms of law and ethics can aggravate tensions rather than render them productive.

I suspect that 'law' and 'ethics' are proxies for Jewish uniqueness and particularity as against the standards, however idealized, of the general culture. The terms are needed rhetorically to protect distinctive Jewish territory or to subject it to criticism, whether internal or external. The real conceptual work that is being done with these terms is pragmatic rather than semantic: there is a fight going on over who represents Judaism, who has authority, what is the normative view. If you are a halakhist, you can be dismissive of a view if you can characterize it as mere ethics. If you are a liberal Jew, you get to critique the harshness of law in the name of something presumably higher and nobler. 'Law' and 'ethics' thus seem to be contrastive terms. They derive some of their sense, in these modern Jewish treatments, from their contrast to one another. One member of the pair acts as a foil for the other. If the writer holds to the omni-sufficiency of halakhah, he needs 'ethics' as his whipping boy. If the writer holds to the sovereignty of ethics, she needs 'law' to provide the raw material for her idealizations or criticisms. Rhetorical and polemical needs drive the hypostatization of the terms. 
In my view, the better way forward is to say that both 'law' and 'ethics' are terms that do not map entirely well over traditional Jewish materials. The Jewish tradition did not develop such a categorical distinction in the way that Western thought did. There is a holism about the Jewish normative order. We see that holism expressed along another fault line - the modern distinction between deontic and aretaic ethics. Anscombe is herself too categorical in describing traditional Christianity and the Jewish tradition out of which it developed as a 'law ethic,' for there is far more than what corresponds to law going on in Judaism. Like other traditional normative orders, Judaism did not distinguish between obligation and virtue; it did not see an opposition between obeying public norms and cultivating human excellence. The falling out of justice and virtue that marks modern ethics would be wholly unintelligible to a traditional Jewish moralist. It is an obligation of halakhah to cultivate character, as much as it is an obligation to observe the Sabbath. Indeed, Sabbath observance as far back as Deuteronomy 5:12-15 seems intended to develop virtuous dispositions toward sympathy, understanding, and solidarity. While a Western legal system wants to inculcate the attitude of law-abidingness, even law-affirmation, it is typically unconcerned with dispositions such as love, self-criticism, or awe. Ahavat ha-briyot, heshbon ha-nefesh, and yirat shamayim as these dispositions are called in Hebrew are as much elements of halakhah as kashrut and festivals. It is impossible to decide which Jewish norms should be allocated to ethics and which to law because these categories are ill-suited to those norms. The integration of those norms into a complex whole requires theorizing in its own terms not in terms of borrowed oppositions and dichotomies.

What then of theorizing Jewish ethics? Is Jewish ethics a legitimate concept or should we avoid it? To the extent that we want to continue to speak about the normative dimensions of Judaism, and to speak of them in English, the use of such terms is unavoidable. Our aim should be to avoid using them thoughtlessly, using them in such a way as to generate confusion. A capacious and minimalist approach to the notion Jewish ethics would be best. I would suggest that we employ the term 'Jewish ethics' to indicate 'reflection on character and conduct.' Such reflection occurs in 'legal' sources; it occurs in traditional virtue literature (sifrut ha-musar); it occurs in liturgical and secular poetry; it occurs in philosophical texts where it becomes highly reflexive and thematic. Jewish ethics thus directs us to look for thought about a broad range of ethical considerations, but not only those. It cannot be separated from metaphysics, theology, narrative, and streams of authoritative texts descending from the past.

'Jewish ethics' should not rival, dominate, or compete with other ways of thinking about the normative in Judaism. It should integrate not isolate those perspectives. It is not, properly conceived, the Judaism of the assimilated. It is that form of inquiry which seeks to evoke the wisdom of Judaism as it pertains to conduct and character, to what is entailed by the quest to live rightly and well.

\section{Acknowledgement}

The author wishes to express his gratitude to Prof. Lenn E. Goodman, Andrew W. Mellon Professor in the Humanities at Vanderbilt University, for his invitation to give an earlier version of this paper at a colloquy of the Philosophy Department at Vanderbilt.

\section{References}

1. Anscombe G.E.M., The Collected Philosophical Papers of G.E.M. Anscombe, Vol. III., Minneapolis: University of Minnesota Press, 1981.

2. Dan J., Jewish Mysticism and Jewish Ethics, Seattle: University of Washington Press, 1986.

3. Federbush S., Ha-Musar ve-Ha-Mishpat b'Yisrael, Jerusalem: Mossad Ha-Rav Kook, 1979, pp. 11-21.

4. Geuss R., Outside Ethics, Princeton: Princeton University Press, 2005. 
5. Kant I., The Metaphysics of Morals, ed. Mary Gregor, Cambridge: Cambridge University Press, 1996.

6. Kellner M., ed., Contemporary Jewish Ethic, New York: Hebrew Publishing Company, 1978.

7. Lazarus M., Die Ethik des Judentums, Frankfurt a.M.: J. Kaufmann, 1898.

8. Mittleman A., A Short History of Jewish Ethics, Oxford: Wiley Blackwell, 2012.

9. Soloveitchik J. B., Halakhic Man, trans. Lawrence Kaplan, Philadelphia: Jewish Publication Society, 1983.

10. Williams B., Ethics and the Limits of Philosophy, Cambridge: Harvard University Press, 1985.

11. Wyschogrod M., The Body of Faith, San Francisco: Harper \& Row, 1989.

\section{Notes}

1. Wyschogrod's complete argument is a great deal more complex than the headline that I am extracting from it. In fact, he condemns the abstraction of a universalizing, rationalistic ethics from Judaism and he condemns seeing Jewish law as ethically irrelevant. Jewish ethics is tied to law but also tied to the Jewish people. The law entails divine commands that can be immoral from the point of view of "pure ethics." Jewish ethics becomes a kind of tribal normativity, shaped by God-given Jewish law and the incarnation of divinity in the Jewish people.

2. Dan, in Jewish Mysticism and Jewish Ethics, first argues that it would be right to call the halakhah as a whole 'a comprehensive system of ethical behavior.' But he finds that constitution of Jewish ethics too sweeping and so retreats to the more restrained view that ethics is a supererogatory complement to halakhah. Halakhah establishes a legal minimum while 'ethics and the aggadah describe the unending road toward perfection.' His view thus combines the idea of ethics as a higher, more exigent standard rooted in inwardness with the idea that ethics issues into going beyond the law in one's action. He also wants to ground ethics on aggadah, broadly speaking, which complements in classical terms the halakhah [2, pp. 3-4].

3. The material on Lazarus is partially taken from [8, pp. 181-184] and is used with the kind permission of Blackwell Publishing Ltd.

4. As Baumgardt explains, Lazarus followed an early post-Kantian philosopher named Johann Friedrich Herbart. Herbart eschewed the speculative metaphysics of Fichte and Schelling. He provided a more congenial model for a moral philosophy, such as Lazarus's, that tried to remain anchored in empirical, psychological observation. See Baumgardt, The Ethics of Lazarus and Steinthal, p. 205.

5. Rotenstreich, Jewish Philosophy in Modern Times, p. 46. The extent to which Kant divorces the noumenal moral law from the phenomenal condition of human psychology seems to me easy to exaggerate. See, for example, The Metaphysics of Morals, Part II, section XII where Kant discusses 'concepts of what is presupposed on the part of feeling by the mind's receptivity to concepts of duty as such.' See [5, p. 159ff.]

6. This essay is found in (Kellner 1978), pp. 102-123.

7. [10, p. 38]. For his sustained criticism of modern ethics as a 'morality system,' see Chapter 10.

8. Originally in Philosophy, 33 (1958), reprinted in [1, p. 30]. So too [4], Chapter 3. On Geuss's view, the central question of philosophical ethics - what ought I to do? - derives from a medieval world in which doing God's will was the paramount human task. With the loss of that world, a secularized equivalent takes its place. Ethics becomes an ever more total domain, compensating for the absence of the divine. It is difficult, although worthwhile for Geuss, to get 'outside' ethics. 